\title{
Utilizing Children's Song Videos To Create A Religious Character In Children With Intellectual Disabilities
}

\section{Billa Krisbiyanti}

Drama, Dance, and Music Education Department, Faculty of Language and Arts, Universitas Negeri Semarang, Indonesia.

\section{Udi Utomo ${ }^{\varpi 1}$}

Drama, Dance, and Music Education Department, Faculty of Language and Arts, Universitas Negeri Semarang, Indonesia.

\begin{tabular}{|c|c|}
\hline Article Info & Abstract \\
\hline $\begin{array}{l}\text { Submitted: October, } 2021 \\
\text { Revised: December, } 2021 \\
\text { Accepted:December } 2021 \\
\text { Keywords: } \\
\text { Character education, } \\
\text { religious, video, children's } \\
\text { songs, intellectual disability. }\end{array}$ & $\begin{array}{l}\text { Character education at SLB Negeri } 1 \text { Pemalang has not been able to run optimally since } \\
\text { the emergence of the Covid-19 pandemic affecting the learning activities having to be carried ou } \\
\text { online. However, the efforts made by one of the teachers at SLB Negeri } 1 \text { Pemalang to create } \\
\text { religious characters through song videos show that character education can still be done by utilizing } \\
\text { technological advances in online learning. This study aims to describe and analyze children's song } \\
\text { videos used by teachers to create religious characters for students with intellectual disabilities o } \\
\text { class IV C at SLB Negeri } 1 \text { Pemalang. The research method of this study is descriptive qualitative } \\
\text { The results of this study show that the videos of songs by Nussa and Rara entitled "Rukun Iman" } \\
\text { "Rukun Islam", and "Berkata Baik atau Diam" can be used by teachers to create religious character } \\
\text { for students with intellectual disabilities. The three songs have elements of similar musicality tha } \\
\text { are easy to be learned and mastered by students in the children's age group. The lyrics of these songs } \\
\text { contain Islamic trilogy in the form of basic concepts of character building, namely aqidah, sharia } \\
\text { and morals. The three songs are presented in the form of animated videos so that it is interesting. } \\
\text { eases students with intellectual disabilities to accept and understand the learning material provided }\end{array}$ \\
\hline
\end{tabular}




\section{INTRODUCTION}

Character education is important for the Indonesian nation in the globalization era. Character education containing noble values needs to be instilled in schools to create the personality of Indonesia's young generation following the nation's character. Character education does not only include intellectual intelligence but also refers to emotional intelligence and personality according to its objectives in realizing the ideals of the nation. Suyanto says character education is not just a science taught by teachers to students, but character education also builds one's attitude and personality. Character education is directing someone about the procedures for thinking and behaving as an individual characteristic to work together in family life, society, nation, and state(Kristiawan \& Fitria, 2018). Character education will be better if it is taught from an early age. It is following President Jokowi's instruction that character strengthening must be a priority program in the education unit. He makes character strengthening one of his priority programs. He gives a larger portion of character education in elementary schools than in secondary schools. Rohendi says that giving a larger portion is due to the intellectual development of children faster than in adulthood so that the values of character education taught are more easily absorbed and attached to students from an early age. (Mustoip et al., 2018) also argue that a person's character will be difficult to change if it is not formed early on. Therefore, character cultivation is needed starting from the elementary school level. Character education plays an important role in maintaining the existence of a nation and state. Maksudin says that the importance of character education is supported by several things (Soraya, 2020), namely: (1) character is an important part of a person so it must be educated; (2) the character of the younger generation (even the older generation) is currently experiencing erosion, fading, and drying up; (3) life is measured by money so that humans seek money by trying in every way possible; and (4) character plays a role in determining the survival and development of citizens of a country. By instilling character education in students, it is hoped that it can create full awareness in students so that they create personalities. Students are also expected to be able to use their knowledge by the character education for implementing character values so that noble character came true in their daily actions.

In the 21 st century, there are 5 core characters proclaimed by the government in Presidential Regulation Number 87 of 2017, namely (1) religiosity, (2) nationalism, (3) cooperation, (4) independence, and (5) integrity. The five core characters are the minimum number of 18 character values that must be instilled in students in the educational process at school (Mustoip et al., 2018). Religious character is mentioned as one of the important characters that must be instilled in students. Religious character directs humans to be guided by the religion they adhere to maintain a person's good relationship with their God and human beings.

With the advancement and development of technology, religious character values can be taught by utilizing learning media. The use of learning media can provide convenience for teachers in teaching activities. In addition, the use of learning media can create interesting learning so it can increase student motivation in learning activities. Learning media has various types. The selection of the learning media type given to students must adjust the topic to be discussed.

In this study, song videos were used to instill religious character values in students with special needs, especially students with intellectual disabilities. Intellectual disability students in class IV C follow the same technological developments as millennial children in general. These advances make them addicted to the device and spend too much time playing. Therefore, the children are often negligent in carrying out their worship to God and there is a decrease in 
motivation in learning. Video media is chosen as a tool for learning in the intellectual disability class because it has several advantages. This video media is used to make it easier for intellectual disability students to learn and understand the character education material taught. On the other hand, intellectual disability students can train their emotions and empathy by looking at events in the song videos shown. Giving the right video media to intellectual disability students is expected to create effective learning by adjusting their needs and mental abilities. Song videos that contain visual and audiovisual media can also function to strengthen the theme (Wafa et al., 2020).

Children's song videos used by teachers for intellectual disability students in class IV $\mathrm{C}$ with an emphasis on the formation of religious characters. We need to know that intellectual disability children have difficulty understanding things because of intellectual limitations. Children with intellectual disabilities are faster to catch and understand the material given in a fun way. Therefore, the teacher chose to teach children's songs accompanied by attractive visuals through videos of religious songs in the animation of Nussa and Rara as an effort to create the religious characters in intellectual disability students.

\section{METHOD}

This research used qualitativedescriptive research. Qualitative research is a strategy used to find information about the quality of a thing presented in the form of an explanation or elaboration by focusing on the exploration of purposes, definitions, concepts, uniqueness, signs, and phenomena. Focus and multimethods that are natural and comprehensive (Yusuf, 2014). Data collection techniques used are observation, interviews, and documentation. The researchers used an interactive model of data analysis technique consisting of three factors, namely data reduction, data presentation, and conclusions. This research tested the validity of the data using triangulation of data collection techniques. Sugiyono (Alfansyur \& Mariyani, 2020) says that technical triangulation is carried out to check the validity of the data through several different data collection techniques to find the truth of data from the same source. The researchers used observation, interview, and documentation techniques and then found the truth through the same data source to conclude.

\section{RESULTS AND DISCUSSION}

Children's songs are songs created to be consumed by children. In the creation of children's songs, it is necessary to consider all elements that are according to the character of the child. In the past, many children's songwriters such as Ibu Sud, AT. Mahmud, and Pak Kasur whose songs are still sung by children to this day. The creation of these songs is not without purpose but it has the meaning contained in the lyrics of the song. These songs play a special role in increasing self-confidence, growing positive characters, and building creativity. The songs contain a moral message for children. For example, the song "Bangun Tidur" teaches children to take a shower and brush their teeth after waking up and help mothers to clean the bed after use. It indicates that the lyrics of the song contain character education, namely being independent and responsible.

The songs chosen by the teachers in class IV C to create religious characters in intellectual disability students are taken from the animated video of Nussa and Rara produced by the animation studio, The Little Giantz. The production studio is pioneered by Mario Irwinsyah in collaboration with 4 Stripe Production. The first animated episode of Nussa and Rara was relayed last November 2018. This animated video is available on the YouTube platform under the account name Nussa Official. This animation tells about the daily life of the two main characters, namely Nussa, a 9-year-old boy, and his younger sister, Rara (Melina, 2018). 


\section{Song Title and Theme}

Song children used by Mrs. Lily in the religious character learning in class IV C entitled "Rukun Iman", "Rukun Islam", and "Berkata Baik atau Diam". The three songs have the same theme, namely the theme of religion. The national curriculum applied in the 21st century mentions a religious character as one of the important characters that must be instilled in students in (Hidayat, 2020). Therefore, children's songs with religious themes can be used to assist teachers in instilling religious values in children nowadays. The curriculum used at this time can be used as a reference for teachers in choosing the theme of the song taught to children (Matondang, 2005). The process of creating childrens' religious character will be greatly helped by utilizing children's songs containing religious values to maintain children's spirituality during the Covid-19 pandemic through online learning.

\section{Song Melody}

Melody is a tone or sound arranged in an orderly and sequential manner that expresses an idea (Jamalus in Andika Gutama, 2020). Fathur Rasyid (inc Anggraeni, 2016)argues that one of the characteristics of a good song for children is that the melody is taught to be easy to master. The three songs above meet the criteria for a good song to teach to children because the composition of the notes is easy to master. This can be shown from the area of the tone of the three songs. Low voices in children have the a-d' tone area, while high voices in children have the c'$\mathrm{f}^{\prime \prime}$ tone area (Wulandari, 2008). The song "Rukun Iman" has the lowest note c' and the highest note $c$ ". The song "Rukun Islam" has the lowest note $\mathrm{g}$ and the highest note a'. The song "Berkata Baik atau Diam" has the lowest note of $g$ and the highest note c". The three songs meet the criteria for a good song for children where the area of the tone can be reached by children, it makes it easy for children to sing the song (Matondang, 2005). The melody also contains repetition. Songs with repetition above are needed to ease children learning something new (Matondang, 2005).

\section{Song Rhythm}

Rhythm is a motion sequence formed by a group of sounds and it is silent with various lengths of time or short lengths to form a rhythm pattern, move according to pulses in a barometric swing (Jamalus in Andika Gutama, 2020). The songs in Nussa and Rara's animated videos have a cheerful musical rhythm. With cheerful music, children can express feelings of pleasure and express them in the form of singing according to the melody and rhythm of the song taught. Therefore, the children will be more enthusiastic and easy to accept the material through the given song and they can imitate the activities carried out by the characters of Nussa and Rara in the song video. The rhythmic patterns used in these songs are not too varied so that children can easily understand and learn the songs.

\section{Song Tempo}

Tempo means the basic speed of music (Roger Kamien in Panjaitan, 2019). Machlis defines tempo as a measure of how fast or slow a song is performed (Panjaitan, 2019). From these two opinions, tempo can be interpreted as a measure of time in music. The use of tempo needs to adjust the atmosphere of the song sung. Normally, the fast tempo is used in songs with happy nuances while the slow tempo is used in songs with sad nuances. The use of tempo needs to adjust the atmosphere of the song sung.

The songs from Nussa and Rara's animated videos have a similar tempo. The song "Rukun Iman" has a tempo of 108 M.M, the song "Rukun Islam" has a tempo of 100 M.M, and the song "Berkata Baik atau Diam" has a tempo of 120 M.M.

The song "Rukun Islam" has 100 M.M tempo which is classified as a song with a tempo of moderato (medium) whose tempo speed ranges from 90 to 104 M.M. Songs with tempo moderato make an impression happy and majestic. This song contains knowledge about the basics of Islamic teachings delivered with great 
pomp without losing the element of joy that is the nature of children. While the songs "Rukun Iman" and "Berkata Baik atau Diam" have tempos of 108 M.M and 120 M.M. The two songs have tempos ranging from 108-116 M.M where the tempo speed belongs to the allegretto category (Mudjilah, 2010). Songs with tempo allegretto make a quick, happy, and exciting impression. Children have a cheerful nature and tend to be hasty or impatient. Therefore, these songs are appropriate if it is taught to children. Songs with allegretto tempo can also provide enthusiasm for children so that they can increase children's learning motivation to understand the character values conveyed by the songwriter. The three songs taught also have a stable tempo or no change in tempo so it eases children to learn and understand the songs.

Adi Putra Panjaitan (2019) in his journal entitled "Kekuatan Musik dalam Pendidikan Karakter Manusia" explains that rhythm and tempo can affect emotions in humans. A person will be floated in a calm and sacred atmosphere when listening to a song with a slow rhythm and tempo while a song with a fast rhythm and tempo can encourage someone to move the body. Therefore, the natural movement in humans will adjust the movement of the rhythm and tempo in the music. It shows that rhythm and tempo can affect humans emotionally, including children. With the explanation above, it can be concluded that the creation of song kids should consider the selection of rhythms and tempos that suit the nature of children. The meaning or message contained in the song can be absorbed well by children with the selection of the right rhythm and tempo. In addition, the rhythm and tempo of children's songs can train children's emotional abilities.

\section{Song Lyric}

lyric is an element that plays an important role in conveying the message of the song. The lyrics of the four songs taught by Mrs. Lili are simple, easy to understand, and not too long. It follows the characteristics of children's songs mentioned by Fathur Rasyid (in Anggraeni, 2016) where the poems and sentences in children's songs should not be too long so that they are easily mastered by children. The lyrics of the children's song delivered by Mrs. Lili in class IV C can be the basis for creating the religious character in students. This can be obtained from the lyrics of the song which contains the trilogy concept of Islamic teachings mentioned by Marzuki (2012), namely the teachings of aqidah, sharia, and morals.

\section{Aqidah Value}

Aqidah is a concept of the study of faith which is the foundation of sharia and morality. Therefore, aqidah can be said as an Islamic belief system consisting of six beliefs that are the basis for Muslims to carry out activities in daily life. These six basic beliefs are known as the pillars of faith (Marzuki, 2015).

The lyrics of the song "Rukun Iman" contain the value of aqidah which contains an invitation to students to believe in the six pillars of faith. The lyrics of the song also mention the six aspects of the pillars of faith that must be believed by Muslims, namely belief in Allah, belief in angels, belief in the book of which God is the author, belief in all Prophets, belief in the Day of Judgment, and belief in qadha and qadar. The song "Rukun Iman" contains the value of aqidah taught to foster a sense of love and faith in students towards Allah and all aspects related to Islam, namely belief in Allah, belief in angels, belief in the book of which God is the author, belief in all Prophets, belief in the Day of Judgment, and belief in qadha and qadar. This aqidah has an important role to underlie the concept of sharia and morality

\section{Sharia Value}

Sharia means a religious regulation that has been set by Allah for Muslims. It is based on the guidelines of human life, namely Al-Qur'an and Hadith/Sunnah of the Prophet (Yusuf Mussa in Marzuki, 2015). Sharia is a continuation of aqidah. 
The two are closely related and cannot be separated. Aqidah is the foundation that fortifies sharia, while sharia is the manifestation of the function of the heart in aqidah (Syaltut in Marzuki, 2012). Sharia is divided into two, namely worship and muamalah. Worship is manifested in the human relationship with Allah, namely the pillars of Islam, while muamalah is manifested in human relations with each other, namely marital, inheritable, criminal, economic, political, judicial, and international relations.

Song lyric "Rukun Islam" contains sharia values taught to regulate human relations with Allah through worship, namely saying the two sentences of shahada, praying, fasting in the month of Ramadan, paying zakat, and going to hajj for those who can afford it. The lyric of the song mentions the five aspects of the pillars of Islam that must be practiced by Muslims. The lyric of the song has an invitation message to memorize the pillars of Islam because Allah loves people who memorize and practice the five pillars of Islam. The lyric of the song "Rukun Islam" contains sharia values which are the manifestation of the aqidah basic concept contained in the lyric of the song "Rukun Iman". After students apply the concept of aqidah through the lyric of the song "Rukun Iman", students are expected to realize their faith in the concept of sharia by practicing the five pillars of Islam contained in the song "Rukun Islam".

\section{Moral Value}

Moral is the study concept of the Ihsan which has an important position as a continuation of aqidah and sharia. Moral is based on a person's awareness that all deeds or actions in the world are always under the supervision of Allah. It can cause people to be afraid Allah so that they try to always do good.

Song lyric "Berkata Baik atau Diam" contains moral values. The lyric of the song is about a human relationship. In the lyric, it is said that a Muslim should speak only about good things. Silence is better than talking about bad things that can hurt other people, including parents and others. The lyric also mentions the importance of guarding the tongue because by keeping the tongue there will be a guarantee in the form of heaven from Allah. The lyric of the song shows that humans need to maintain their morals towards others. Good morals can be a strong foundation for maintaining human relationships with others. In addition, good morals can prevent humans from heart disease which can reduce the reward in worship. This morality is a process of applying the concept of aqidah and sharia. Morals are likened to the perfection of a building built with a strong foundation and superior materials in the form of aqidah and sharia. Therefore, good morals can be manifested in people if they also have good aqidah and sharia.

The three children's songs that have been described above contain three concepts of Islamic teachings, namely aqidah, sharia, and morals. The three are closely related and cannot be separated. Aqidah contains a belief system used as the basis for Muslims in religion, sharia contains a legal system in the form of rules and regulations describing the function of religion, and morality is a continuation of aqidah and sharia containing a system of ethical values related to the direction and purpose of religion. Thus, it is clear that the three basic concepts above must be embedded and attached to Muslims. These three concepts are known as the trilogy of Islamic teachings.

The songs above are used to realize the religious character of students through the basic concepts of Islamic teachings contained in the lyrics of the song. To ease the understanding of readers, the researchers analogize the three concepts of Islamic teachings above as "a house". In building a house, it takes a strong foundation to become a strong building. The song "Rukun Iman" can be used as the main foundation in the formation of religious character because it contains the concept of aqidah serving to teach the basics of a Muslim's faith to students. The strength of a house depends on the quality of the materials used. The song "Rukun Islam" contains the concept of sharia 
regulating the relationship between humans and God through worship, namely saying shahada, praying, fasting in Ramadan, paying zakat, and going hajj if you can. The five pillars of Islam are likened to building materials. The perfection of a house is created from the superior quality of building materials. If the five pillars of Islam are implemented properly, a religious character will be formed in students perfectly. The song "Berkata Baik atau Diam" contains a moral concept that teaches students to always do good, including in terms of keeping words. This song teaches about morals towards humans to others as a manifestation of the concept of aqidah in the song "Rukun Iman" and the concept of sharia in the song "Rukun Islam". Morals are likened to the house itself. With a strong foundation namely aqidah and superior building materials namely sharia, it will realize a perfect house, namely morality. This house will always be attached to heat and rain every day. This building will still stand strong if the owner performs the regular maintenance. Similarly, a person's morals will be perfectly formed if they are based on strong aqidah and sharia. People can pass the obstacles in their lives with the perfection of morality.

The process of character education in children requires special strategies so that these character values can be conveyed well. The delivery must adapt children's characters who like things that relate to games and imagination. Therefore, the three songs described above used by class IV $\mathrm{C}$ teachers aim to create religious characters in their students. The simple way that teachers do to maintain a good relationship between students and God is by introducing the six pillars of faith through learning the song "Rukun Iman" to create students' belief in Allah, belief in angels, belief in the book of which God is the author, belief in all Prophets, belief in the Day of Judgment, and belief in qadha and qadar. The five pillars of Islam are also introduced to students as the basis for student learning in worship through the song "Rukun Islam". Students need to understand the basic things that must be done and practiced by them as Muslims. This understanding can be the basis for students to behave and act following Islamic teachings. The teacher also uses children's songs that contain the concept of morality, one of which is through the song "Berkata Baik atau Diam". The good habits taught to students in this song are very influential on the formation of their character so that they will create good characters embedded until they grow up. The implantation of good character will also have a good impact on their lives in the future.

\section{Song Video}

Students in class IV C are intellectual disability children who have intellectual limitations so that it is difficult to understand the material taught. Halgin and Whitebour (in Onyekuru \& Njoku, 2012) explain that intellectual disability is a condition from birth that is characterized by intellectual intelligence below the average, namely an IQ of below 70 . Grossman Grossman (in Kiarie, 2006) also defines that intellectual disability has significantly below-average intellectual function and deficiencies in self-adjusting behavior that take place during development. With these various obstacles, the learning materials delivered will be more difficult for intellectual disability children to accept and understand than children in general. The material must be given repeatedly so that it causes boredom which can cause a decrease in student motivation to learn. Therefore, intellectual disability children need special attention and actions in teaching and learning activities to help their intellectual development.

At the beginning of the pandemic, Mrs. Lily only used image media to clarify the material taught. Mrs. Lily thought that the media can provide a lot of convenience in the learning process, online and offline. Image media can also be used to clarify objects that are difficult to import directly, such as rare objects, expensive items, large items, or dangerous items Grossman (in Kiarie, 2006). One example of an image 
used by Mrs. Lily in her study is the Kaaba. The Kaaba is an object that is very large in size and difficult to reach so the children are only given an illustration using photos of the Kaaba sourced from the internet. It is conveyed by Adebisi et al. (2015), where media images can be created or obtained with the help of technology or the internet.

One of the advantages of using media in learning according to Taiwo (2009)is useful as a substitute for teachers and a complement for teachers in increasing effectiveness in the classroom. Therefore, Mrs. Lili used image media to clarify the meaning of the materials taught. However, over time, Mrs. Lili saw the emergence of boredom and the loss of student motivation in the learning process. It has been explained by Windiyani et al. (2018) in their journal, that students are more easily bored and show disinterested reactions because the use of media in learning has not been maximized. In line with this statement, Li \& Shieh (2016) argue that the development of global education in recent years has presented a new atmosphere that is plural, innovative, and open due to technological changes and the rapid explosion of knowledge. In this case, teachers are required to master technology by choosing various media supporting the delivery of materials so that it can provide convenience for students in learning.

Finally, Mrs. Lili found a way to reduce boredom and raise motivation for intellectual disability students during online learning by using song videos. Because all intellectual disability students in class IV C have the same belief, namely Islam, the cultivation of religious character values can be carried out simultaneously using song videos containing Islamic values. Finally, Mrs. Lili uses a song video taken from the animation of Nussa and Rara to raise students' motivation to learn. In addition, the video of the song is used by Mrs. Lili to introduce the basic values of Islam to students. According to Sadiman's statement regarding the criteria of a good video to be taught to students in elementary school is that the video media used must follow the learning objectives (Sadiman, 2014). The song videos taught contain the concepts of Islamic teachings where these concepts are the basis used to form good character in students. Therefore, the song video used is based on the learning objectives stated by Mrs. Lili, namely forming a religious character.

Arief S. Sadiman (2014, hal. 74) defines video as an audio-visual medium that presents fact or fiction (can be in the form of information, education, or instructions) in the form of images and sound. According to Sadiman, Purwono et al. (2014) explain the meaning of audiovisual media. They state that media is a combination of audio that can be heard and visuals that can be seen, such as video recordings. Hayati et al. (2017) also describe the meaning of audio-visual learning media as intermediary media that can be absorbed through viewing and listening activities so that students get knowledge, attitudes, and skills used to achieve learning objectives. Another opinion according to Semenderiadis \& Martidou (2009) video is an audio-visual media that has images and sounds so that it can provide a lot of stimulation to children. Audio-visual media can help children explore the world around them, experiment, creativity, expression, and development of children's thinking power so that the media plays a very important role in the educational process.

The storyline of Nussa and Rara's animated video describes all events or events that occur in the daily life of children. The message of the songs is not only conveyed through the lyrics of the song but also visualized in the form of moving images. It makes the message contained in the song more digestible by showing real examples in video shows so that it eases children to understand concepts and imitate the activities exemplified in the video. The use of video media is not without purpose but can provide many benefits and ease of learning for intellectual disability students.

Intellectual disability students in class IV $\mathrm{C}$ have weak memory and 
comprehension skills so that it required maximum use of learning devices or media. It follows the opinion of Wei et al. (2011) supported by Conklin (2016) where teachers can create a pleasant learning atmosphere (joyful learning) in the classroom with the use of learning devices or media. The monotonous class atmosphere can be changed to be varied and fun with the help of learning media. The use of interesting video media can overcome the boredom of learning for intellectual disability students. The use of Nussa and Rara's song videos in class IV $\mathrm{C}$ can overcome the student boredom because this video contains animated cartoons according to the world of children who are more inclined to play activities. The learning materials that are initially difficult to accept and boring become more interesting if it is delivered in the form of a song video accompanied by animation that children like. It is following Arief S. Sadiman's statement (2014, p. 83) that the use of interesting video media will indirectly focus students' attention on learning materials that can give meaning to long-term memory. According to Sadiman, Kurniawan \& Trisharsiwi (2016) state that providing interesting learning media will make students happy and enthusiastic in participating in the learning process so that they can maximize their learning outcomes. Yoon \& Kim (2011) also argue that students will be more motivated to learn if there is something important or interesting. Motivation and enthusiasm will appear by themselves in students if the teacher can utilize learning media appropriately. It is useful to ease the achievement of learning objectives. Based on Indaryati \& Jailani (2015) a fun learning process will make students easily increase motivation and learning achievement in students.

According to Mrs. Lili, the help of video media can help intellectual disability children to understand the learning material. Intellectual disability children more easily learn and understand learning material with light and simple video media. The use of video can prevent verbalism that the child only knows the words without understanding the meaning. For intellectual disability children, the use of this video is useful for helping children's thinking processes, even though the understanding of these materials is very simple (Lestari \& Handayani, 2019). It proves that the selection of a simple song video is the right step to facilitate the delivery of learning materials to intellectual disability students.

\section{CONCLUSION}

Based on the research results, the researchers conclude that teachers can use Nussa and Rara's song videos entitled "Rukun Iman", "Rukun Islam", and "Berkata Baik atau Diam" to create religious characters in intellectual disability students through online learning during the Covid-19 pandemic. The three songs have elements of similar musicality that are easy to learn and master by students in the children's age group. The three songs have themes, melodies, rhythms, tempos, and lyrics that meet the criteria for good songs to be taught to students in the children's age group. The lyrics of the songs contain a trilogy of Islamic teachings that must be instilled in children as the basic concept of forming a Muslim's religious character, namely aqidah, sharia, and morals. Aqidah values are contained in the song "Rukun Iman", sharia values are contained in the song "Rukun Islam", and moral values are contained in the song "Berkata Baik atau Diam". The three songs are presented in the form of animated videos so that it is interesting and ease intellectual disability students to accept and understand the learning materials provided.

\section{REFERENCES}

Adebisi, R. O., Liman, N. A., \& Longpoe, P. K. (2015). Using Assistive Technology in Teaching Children with Learning Disabilities in the 21st Century. Journal of Education and Practice, 6(24), 14-21. 
Alfansyur, A., \& Mariyani. (2020). Seni Mengelola Data: Penerapan Triangulasi Teknik, Sumber dan Waktu pada Penelitian Pendidikan Sosial. Historis: Jurnal Kajian, Penelitian \& Pengembangan Pendidikan Sejarah, 5(2), 146-150.

Anggraeni, S. W. (2016). Penggunaan Media Lagu Anak Dalam Meningkatkan Hasil Pembelajaran Menulis Puisi. Jurnal Sekolah Dasar, 1(1), 49-60.

Conklin, H. G. (2016). Toward More Joyful Learning: Integrating Play Into Frameworks of Middle Grades Teaching. American Educational Research Journal, 20(10), 1-29. https://doi.org/10.3102/000283121 4549451

Hayati, N., Ahmad, M. Y., \& Harianto, F. (2017). Hubungan Penggunaan Media Pembelajaran Audio Visual dengan Minat Peserta Didik pada Pembelajaran Pendidikan Agama Islam di SMAN 1 Bangkinang Kota. Jurnal Al-Hikmah, 14(2), 160-180.

Hidayat, O. S. (2020). Pendidikan Karakter Anak Sesuai Pembelajaran Abad ke-21. Edura-UNJ.

Indaryati, \& Jailani. (2015). Pengembangan Media Komik Pembelajaran Matematika Meningkatkan Motivasi dan Prestasi Belajar Siswa Kelas V. Jurnal Prima Edukasia, 3(1), 84-96.

Kiarie, M. W. (2006). Educational Services for Students with Mental Retardation in Kenya. International Journal of Special Education, 21(2), 47-54.

Kristiawan, M., \& Fitria, H. (2018). Menumbuhkan Rasa Cinta Kepada Allah dan Mahluknya pada Anak Usia 5-6 Tahun. Thufula: Jurnal Inovasi Pendidikan Guru Raudhatul Athfal, 6(2).
Kurniawan, T. D., \& Trisharsiwi. (2016). Pengaruh Penggunaan Media Video Pembelajaran Terhadap Prestasi Belajar Ilmu Pengetahuan Sosial Siswa Kelas V SD Se-Kecamatan Gedangsari Gunungkidul Tahun Ajaran 2015/2016. Trihayu: Jurnal Pendidikan Ke-SD-An, 3(1), 21-26.

Lestari, S., \& Handayani, W. (2019). Media Gambar untuk Meningkatkan Daya Tarik Siswa Kelas 1C SLBN Salatiga Dalam Belajar Matematika. 2, 349354.

Li, J. yi, \& Shieh, C. (2016). A Study on the Effects of Multiple Goal Orientation on Learning Motivation and Learning Behaviors. Eurasia Journal of Mathematics, 12(1), 161172.

Marzuki. (2012). Pendidikan Karakter Mahasiswa Melalui Pendidikan Agama Islam di Perguruan Tinggi Umum. Ombak.

Marzuki. (2015). Pendidikan Karakter Islam. AMZAH.

Matondang, E. M. (2005). Menumbuhkan Minat Belajar Bahasa Inggris Anak Usia Dini Melalui Music and Movement (Gerak dan Lagu). Jurnal Pendidikan Penabur, 5, 128-136.

Mudjilah, H. S. (2010). TEORI MUSIK 1.

Mustoip, S., Japar, M., \& Zulela. (2018). Implementasi Pendidikan Karakter. CV Jakad Publishing.

Obradovic, S., Bjekic, D., \& Zlatic, L. (2015). Creative Teaching with ICT Support for Students with Specific Learning Disabilities. Procedia Social and Behavioral Sciences, 203(3), 291296.

https://doi.org/10.1016/j.sbspro.20 15.08.297 
Onyekuru, B. U. D., \& Njoku, J. (2012). Classroom Management of Mental Retardation. International Journal of Learning \& Development, 2(5), 105111.

Panjaitan, A. P. (2019). Kekuatan Musik Dalam Pendidikan Karakter Manusia. Jurnal Melintas, 35(2), 174194.

Purwono, J., Yutmini, S., \& Anitah, S. (2014). Penggunaan Media Audio Visual pada Mata Pelajaran Ilmu Pengetahuan Alam di Sekolah Menengah Pertama Negeri 1 Pacitan. Jurnal Teknologi Pendidikan Dan Pembelajaran, 2(2), 127-144.

Semenderiadis, T., \& Martidou, R. (2009). Using Audiovisual Media in Nursery School, Within The Framework of The Interdisciplinary Approach. Synergies Sud-Est Europeen n'2, 65-76.

Soraya, S. Z. (2020). Penguatan Pendidikan Karakter untuk Membangun Peradaban Bangsa. Southeast Asian Journal of Islamic Education Management, 1(1), 74-81.

Taiwo, S. (2009). Teachers' Perception of The Role of Media in Classroom Teaching in Secondary Schools. TOJET: The Turkish Online Journal of Educational Technology, 8(1), 75-83.

Wafa, M. U., Purwani, N., \& Malik, A. (2020). Characteristics of Titounis Children Songs: A Study of Songs, Music Instruments and Onomatopoeia. Harmonia: Journal of Arts Research And Education, 20(2). https://doi.org/https://doi.org/10. 15294/harmonia.v20i2.25539

Wei, C., Hung, I.-C., Lee, L., \& Chen, N.S. (2011). A Joyful Classroom Learning System With Robot Learning Companion for Children to Learn Mathematics Multiplication. TOJET: The Turkish Online Journal of
Educational Technology, 10(2), 11-23.

Windiyani, T., Novita, L., \& Permatasari, A. (2018). Penggunaan Media Pembelajaran Gambar Fotografi pada Mata Pelajaran Ilmu Pengetahuan Sosial Siswa Sekolah Dasar. Jurnal JPSD Untirta, 4(1), 91101.

Wulandari, R. (2008). Karakteristik Lagu yang Sesuai Untuk Anak Ditinjau dari Segi Ambitus. Jurnal UNY, 2.

Yoon, J.-O., \& Kim, M. (2011). The Effects of Captions on Deaf Students Content Comprehension, Cognitive Load, and Motivation in Online Learning. American Annals of the Deaf, 156(3), 283-289.

Yusuf, A. M. (2014). Metode Penelitian Kualitatif, Kuantitatif \& Penelitian Gabungan. Prenadamedia Group. 